\title{
Fingerprinting of corundum (ruby) from Fiskenæsset, West Greenland
}

\author{
Nynke Keulen and Per Kalvig
}

Since the late 1960s, it has been known that pink and red corundum occur in the area near Fiskenæsset (Qeqertarsuatsiaat) in southern West Greenland. Corundum is hosted in the Fiskenæsset complex, which is part of the Archaean basement of the North Atlantic Craton. To date, c. 40 corundum localities with a wide range of quality are known in the area - a few localities yield stones of gem quality. The most promising locality, Aappaluttoq, is likely to be mined in the foreseeable future by the Canadian company True North Gems (Figs 1, 2A). Red corundum of gem quality is called ruby; gem quality corundum of other colours (e.g. pink, yellow or blue) is called pink sapphire, yellow sapphire etc., while the blue gem corundum is sapphire. Red, pink and blue corundum are also known in smaller quantities from other areas in Greenland.

\section{The Fiskenæsset complex}

The Fiskenæsset complex (Fig. 1) comprises a series of intrusive sheets of anorthosite, leucogabbro, gabbro and ultramafic rocks (Myers 1985), and is interpreted as derived from a supra-subduction setting, while the associated amphibolites stem from a mid-oceanic ridge to island arc basalt precursor (Polat et al. 2009). The greater Fiskenæsset region was meta- morphosed c. 2.85-2.80 Ga ago at mid- to upper amphibolite-facies temperatures and pressures, reaching granulite facies conditions near the village of Fiskenæsset (McGregor \& Friend 1992; Schumacher et al. 2011). At least one generation of the c. 2.71 Ga felsic pegmatite sheets cuts the anorthosite, ultramafic rocks, amphibolite and gneisses and created reaction zones that developed aluminium-rich mineral assemblages derived from the aluminium in the anorthosite rocks (Schumacher et al. 2011; Fig. 2B). These reaction zone assemblages, associated with pegmatitic felsic sheets and the ultramafic bodies, include very coarse-grained, radial anthophyllite \pm green pargasite \pm green or red spinel \pm sapphirine \pm cordierite (up to $30 \mathrm{~cm}$ single crystals) \pm pink corundum, and \pm phlogopite (Schumacher et al. 2011).

This study is a first attempt to find geochemical and mineralogical characteristics that can be used to tie the Greenlandic rubies to their area of origin. This may have practical implications if an operation of rubies and pink sapphires is established in Greenland. Here, we present Laser Ablation Inductively Coupled Plasma Mass Spectrometry (LA-ICPMS) trace-element geochemical and oxygen isotope data of samples from the Fiskenæsset area and other known localities in Greenland (Storø, Maniitsoq, Kapisillit and Nattivit).
Fig. 1. Simplified geological map of the Fiskenæsset area in southern West Greenland showing the investigated pink and red corundum (ruby) localities in the Fiskenæsset complex. Map after Keulen \& Kokfelt et al. (2011). M: Maniitsoq, S: Storø, K: Kapisillit, F: Fiskenæsset, N: Nattivit.

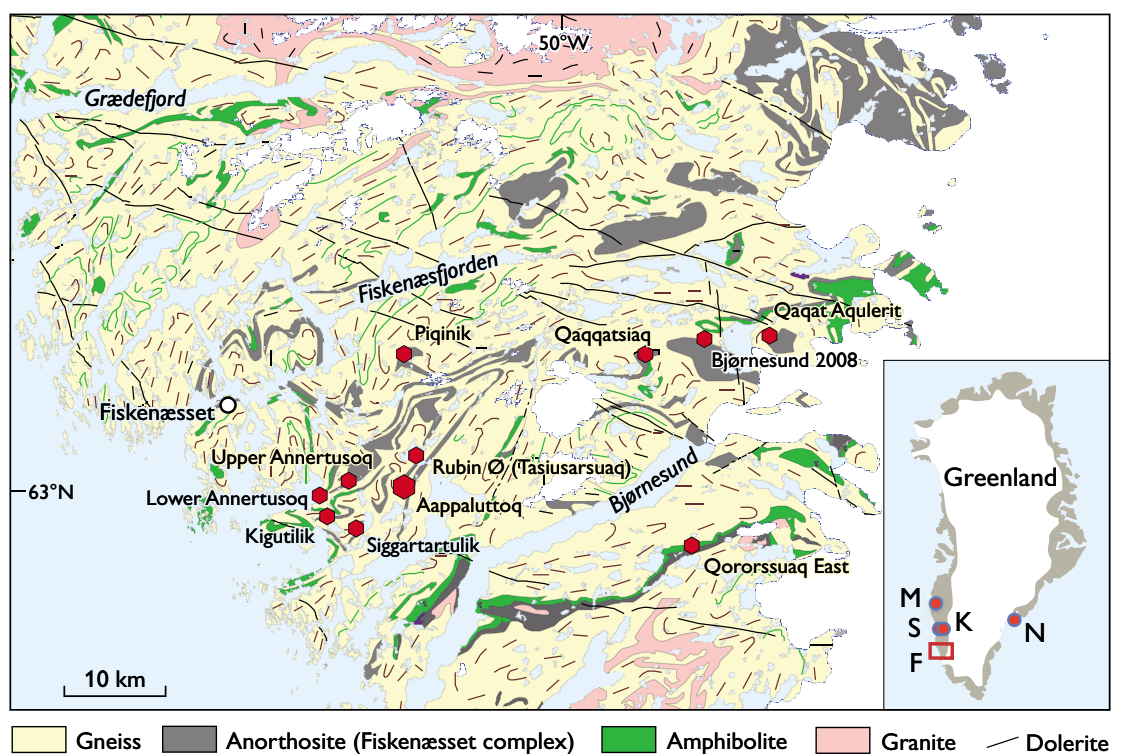



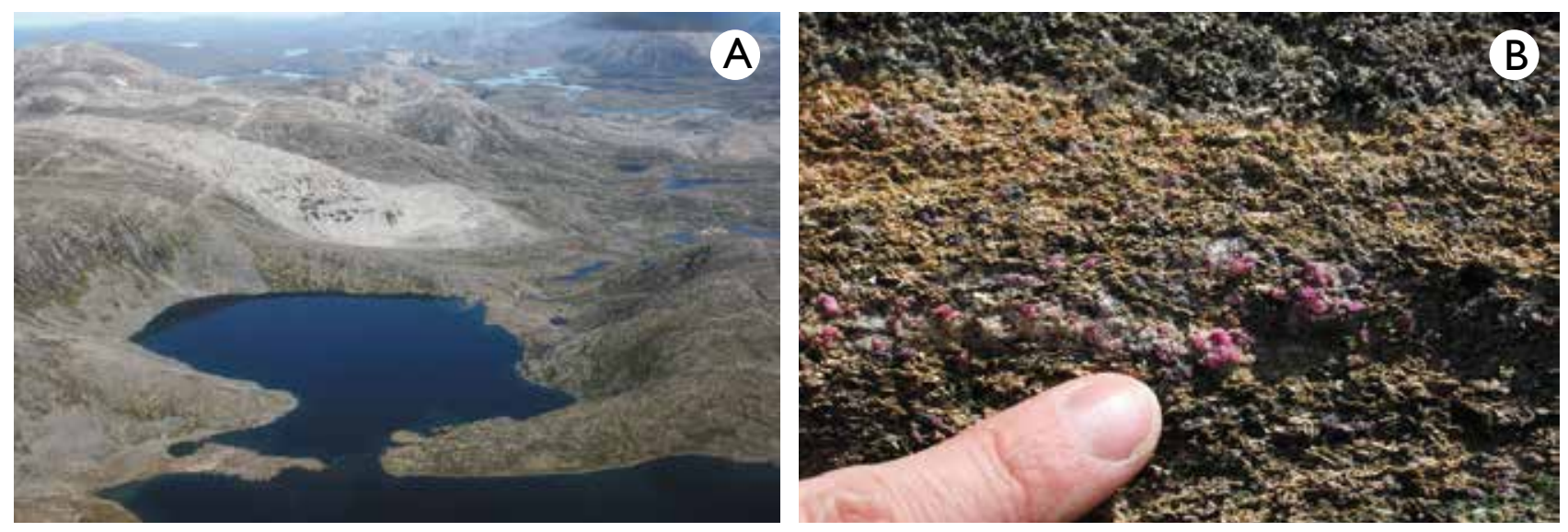

Fig. 2. A: Aappaluttoq, Fiskenæsset, seen from a helicopter towards the north. The white-grey rock is anorthosite. B: Rubies in their host rock at Tasiussarsuaq, Fiskenæsset, Greenland.

\section{Trace-element geochemistry}

Corundum has the chemical formula $\mathrm{Al}_{2} \mathrm{O}_{3}$ and like most other minerals usually includes very small quantities of other elements in its crystal structure. The amounts of these trace elements and their ratios may depend on the geological conditions during the formation of the corundum and therefore usually vary between individual corundum deposits. Twenty-four different elements were analysed for by means of LAICP-MS; however most of them were not detected, including $\mathrm{Sn}, \mathrm{Nb}$, and Ta. Our investigations of the Greenlandic corundum were concentrated on the elements $\mathrm{Mg}, \mathrm{Si}, \mathrm{Ti}, \mathrm{V}$, $\mathrm{Cr}, \mathrm{Fe}$, and $\mathrm{Ga}$, as these elements are present in significant amounts and are also the most widely documented. We used
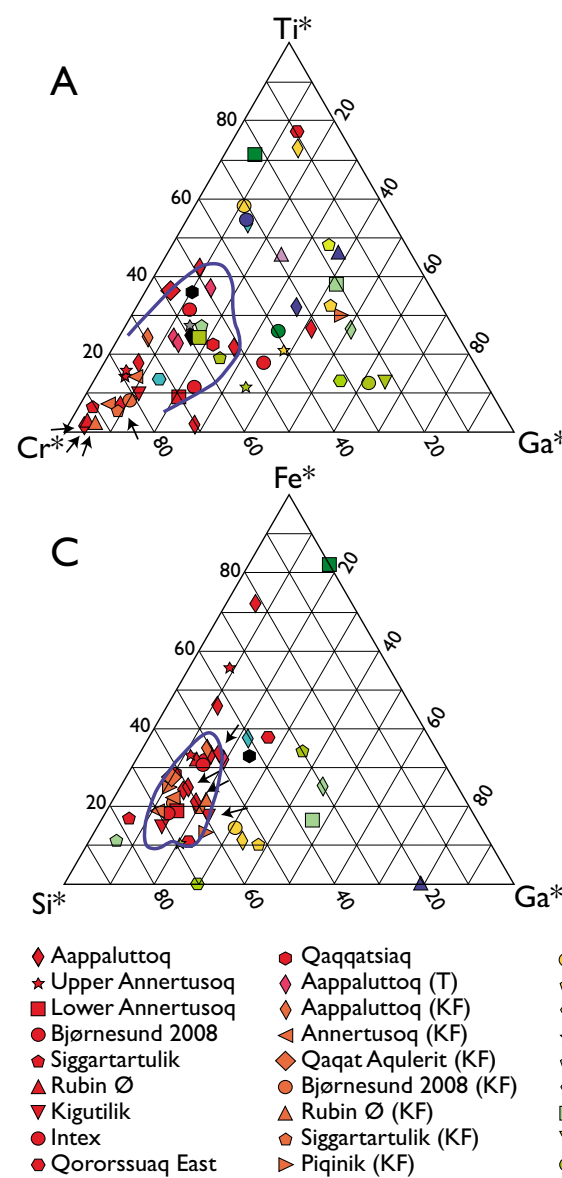
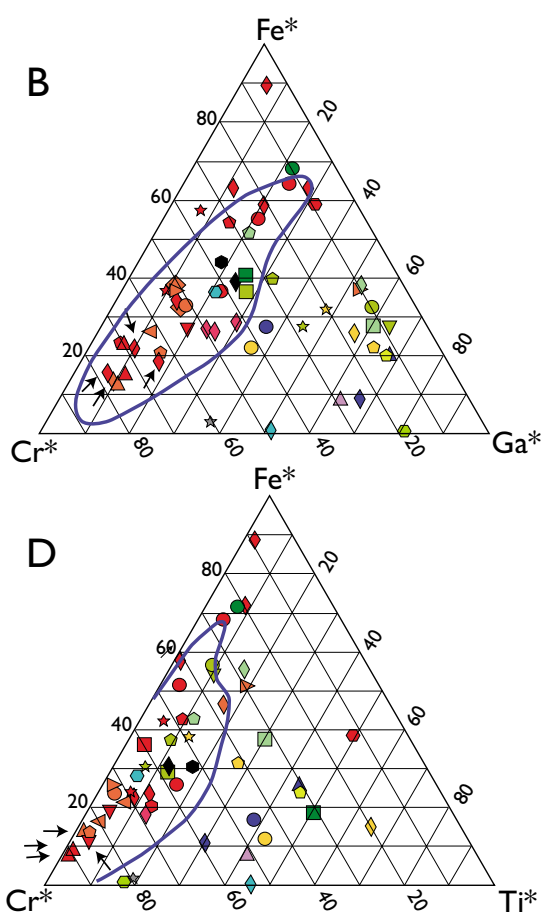

Maniitsoq $\square$ Soamiakatra

$\checkmark$ Storø

कs Nattivit

Winza

$\Delta$ Umba

Umba

$\square$ Tunduru
$\nabla$ Sahabano

- Zazafotsy $\square$ Soamiakatra

$\checkmark$ Pailin $(\mathrm{P})$

- Pailin (C)

- Bo Rai

- Chanthaburi

$\square$ Mong Hsu

- Mogok
- Andilamen
4. Jagdalek $\checkmark$ Jaipur \& Mysore $\triangle$ John Saul - Tsavo

$\checkmark$ Ratnapura $\triangle$ Luc Yen

$\checkmark$ Macedonia

, $80 \%$ Fiskenæsset

$\pi$ best Aappalutto
Fig. 3. Normalised trace-element distributions for A: Ti-Cr-Ga, B: Fe-Cr-Ga, C: Fe-Si-Ga and D: Fe-Cr-Ti in corundum from Fiskenæsset. The data are compared with data on international and Greenlandic corundum occurrences (Calligaro et al. 1999; del Castillo et al. 2009; Kalvig \& Frei 2010; Pornwilard et al. 2011; Rakontondrazafy et al. 2008; Schwarz et al. 2008; Thirangoon 2008). Different colours show different countries. Initials of the authors' names were used where more than one study of the same locality exist. Diagrams were created with WxTernary (Keulen \& Heijboer 2011). 
Fig. $4 . \delta^{18} \mathrm{O}$ values for six samples from Fiskenæsset and four other localities in Greenland. The values are relative to VSMOW (Vienna standard mean ocean water). Colours indicate the approximate colour of the stones. Red boxes and classification as mafic-ultramafic, John Saul mine, and marble after Giuliani et al. (2007).

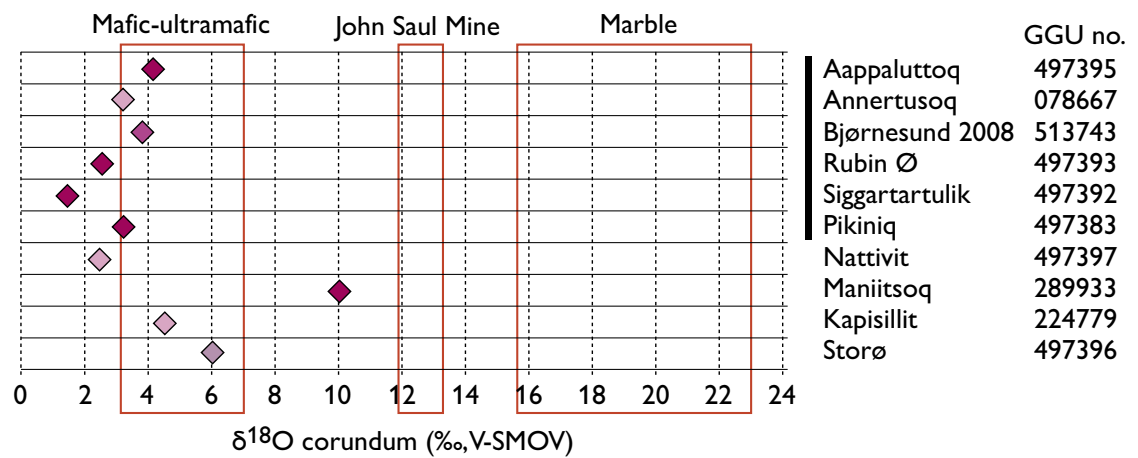

the Laser Ablation Sector-Field Inductively Coupled Plasma Mass Spectrometer (LA-SF-ICP-MS) at the Geological Survey of Denmark and Greenland (Frei \& Gerdes 2009), employing an ELEMENT 2 instrument from Thermo-Fisher Scientific and a UP213 frequency-quintupled Nd:YAG solid state laser system from New Wave Research. Data reduction and determination of concentrations were calculated off-line through the software Iolite using the Trace_Elements_IS routine (Hellstrom et al. 2008). Further details on the methods are found in Keulen \& Kalvig (2013).

Results on the trace-element investigations of corundum grains separated from 21 hand specimens from ten localities in the Fiskenæsset complex are shown with red symbols in the ternary diagrams of Fig. 3. The data for corundum from the Fiskenæsset complex are in good concordance with earlier data from the area (Kalvig \& Frei 2010; Thirangoon 2008). In Fig. 3 they are compared with data from other localities in Greenland and from internationally, well-known, ruby occurrences. Samples from Fiskenæsset show a considerably higher amount of $\mathrm{Cr}$ (up to $14000 \mathrm{ppm}$ ) than samples from other areas in Greenland and most international samples. The Fiskenæsset rubies are relatively rich in $\mathrm{Fe}$ and $\mathrm{Si}$, but relatively poor in $\mathrm{Ti}$ and $\mathrm{Ga}$, while $\mathrm{V}$ and $\mathrm{Mg}$ do not show very distinctive values compared to samples from other areas (Kalvig \& Keulen, 2011).

In order to use trace-element investigations as a fingerprinting tool for rubies it is necessary to investigate the amount of overlap between samples from Fiskenæsset and other localities. The blue lines in Fig. 3 include 80\% (26 out of 32) of the samples from the Fiskenæsset area, based on sample distribution density contouring. Most samples from other localities plot outside the blue line, but an overlapping chemistry is found with samples from Soamiakatra, Ilakaka, and Andilamena in Madagascar, Bo Rai and Chanthaburi in Thailand, Pailin in Cambodia and Winza in Tanzania. Rubies from all these localities are hosted by ultramafic to mafic rocks or are found as placer deposits. This indicates that the trace elements in the rubies derive from the ultramafic rocks that are associated with the anorthosite.
However, if only the four handspecimens with the most transparent and most intensively red-coloured corundum grains from Aappaluttoq, Fiskenæsset, are taken into account, no overlap between these handspecimens and samples from other known ruby occurrences is seen. Corundum from these handspecimens is closest in transparency and colour to the stones that would be sold from a potential mine and therefore represent the Aappaluttoq signature. As these corundum grains have a distinct composition, it can be concluded that trace-element geochemistry with ICP-MS is a helpful tool in fingerprinting rubies from Greenland.

\section{Oxygen isotope geochemistry}

Oxygen isotopic composition measurements were performed on ten samples from Greenland at the University of Lausanne, Switzerland using an isotope ratio mass spectrometer, employing a method similar to that described by Kasemann et al. (2001), see Kalvig \& Keulen (2011) for details.

Six of the samples come from the Fiskenæsset complex. Their $\delta^{18} \mathrm{O}$ values vary between 1.62 and $4.20 \%$ for the Fiskenæsset area, which is low compared to the other areas in Greenland (up to $10.03 \%$ for Maniitsoq) with the exception of one sample from Nattivit (2.41\%; Fig. 4). The $\delta^{18} \mathrm{O}$ values are also low compared to most other investigated corundum deposits worldwide (Giuliani et al. 2007). The lowermost values $\left(\delta^{18} \mathrm{O}<3 \%\right.$ ) are nearly diagnostic for the Fiskenæsset area - worldwide only the placer deposits at Andilamena and Ilakaka in Madagascar and gem-corundum in a cordieritite from Iankaroka, Madagascar have lower reported $\delta^{18} \mathrm{O}$ values. Low $\delta^{18} \mathrm{O}$ values $(\leq 4 \%)$ generally reflect rock types such as mafic rocks, mafic gneiss, basalts, and desilicated pegmatite in mafic rocks (Giuliani et al. 2005), which is in excellent agreement with the mafic to ultramafic setting of the Fiskenæsset rubies. The values for samples from Nattivit, Kapisillit and Storø are also low (2.4, 4.5 and 6.0\%o respectively) and also plot in the mafic-ultramafic field. Unfortunately, no further geological information is available for these specimens and the data can thus not be validated 
against field observations. The value for Maniitsoq with $\delta^{18} \mathrm{O}=10.03 \%$ is typically related to skarns in marble, or to biotitite in gneiss related to shear zones with high fluid activity. The rubies in the investigated sample are assumed to stem from sapphirine-bearing hornblendite. The hornblendite was probably formed in a shear zone with high fluid activity (like the biotitites in Madagascar).

The low $\delta^{18} \mathrm{O}$ values are a potentially useful tool for fingerprinting Greenlandic rubies, especially the very low values for the Fiskenæsset complex and Nattivit, as only few other international occurrences have such low values.

\section{Conclusions}

High confidence fingerprinting of rubies requires a combination of independent analytical methods such as traceelement analyses, oxygen isotope analyses and other studies. The two methods discussed here are efficient in characterising the Fiskenæsset rubies. The ongoing research focuses on optical and physical characteristics, spectroscopy methods and scanning XRF.

\section{Acknowledgements}

This study is part of a collaboration project between the Bureau of Minerals and Petroleum in Nuuk, Greenland and the Geological Survey of Denmark and Greenland. The authors wish to thank Kerstin Bauer and Torsten Vennemann for help with the oxygen isotope analyses.

\section{References}

Calligaro, T., Poirot, J.-P. \& Querré, G. 1999: Trace element fingerprinting of jewellery rubies by external beam PIXE. Nuclear Instruments and Methods in Physics Research B 150, 628-634.

Calvo del Castillo, H., Deprez, N., Dupuis, T., Mathis, F., Deneckere, A., Vandenabeele, P., Calderón, T. \& Strivay, D. 2009: Towards the differentiation of non-treated and treated corundum minerals by ion-beaminduced luminescence and other complementary techniques. Analytical and Bioanalytical Chemistry 394, 1043-1058.

Frei, D. \& Gerdes, A. 2009: Precise and accurate in situ U-Pb dating of zircon with high sample throughput by automated LA-SF-ICP-MS. Chemical Geology 261, 261-270.

Giuliani, G., Fallick, A.E., Garnier, V., France-Lanord, C., Ohnenstetter, D. \& Schwarz, D. 2005: Oxygen isotope composition as a tracer for the origins of rubies and sapphires. Geology 33, 249-252, http://dx.doi. org/10.1130/G21261.1.

Giuliani, G. et al. 2007: Oxygen isotope systematics of gem corundum deposits in Madagascar: relevance for their geological origin. Mineralium Deposita 42, 251-270.
Hellstrom, J., Paton C., Woodhead J. \& Hergt J. 2008: Iolite: software for spatially resolved LA- (quad and MC) ICPMS analysis. In: Sylvester P. (ed.): Laser ablation ICP-MS in the earth sciences: current practices and outstanding issues, 343-348. Mineralogical Association of Canada short course series 40, 343-348.

Kalvig, P. \& Frei, D. 2010: Testing the use of geochemical characteristics of corundum from Greenland as a tool for geographical typing. Danmarks og Grønlands Geologiske Undersøgelse Rapport 2010/68, 36 pp.

Kalvig, P. \& Keulen, N. 2011: Aktiviteter i rubinprojektet 2011 - samarbejdsprojekt med Råstofdirektoratet. Danmarks og Grønlands Geologiske Undersøgelse Rapport 2011/138, 41 pp.

Kasemann, S., Meixner, A., Rocholl, A., Vennemann, T., Schmitt, A. \& Wiedenbeck M. 2001: Boron and oxygen isotope composition of certified reference materials NIST SRM 610/612, and reference materials JB-2G and JR-2G. Geostandards Newsletter 25, 405-416.

Keulen, N. \& Heijboer, T. 2011: The provenance of garnet: semi-automatic plotting and classification of garnet compositions. Geophysical Research Abstracts 13, EGU 2011-4716.

Keulen, N. \& Kalvig, P. 2013: Report of the activities in the ruby project 2012 - a joint project with the Bureau of Minerals and Petroleum. Danmarks og Grønlands Geologiske Undersøgelse Rapport 2013/09, 25 pp.

Keulen, N., Kokfelt, T.F. \& the homogenisation team 2011: A 1:100 000 seamless, digital, internet-based geological map of South-West and southern West Greenland, $61^{\circ} 30^{\prime}-64^{\circ} \mathrm{N}$, http://geuskort.geus.dk/gisfarm/gis_svgreenland.jsp. Copenhagen: Geological Survey of Denmark and Greenland.

McGregor, V.R. \& Friend, C.R.L. 1992: Late Archean prograde amphibolite- to granulite-facies relations in the Fiskenæsesset region, southern West Greenland. The Journal of Geology 100, 207-219.

Myers, J.S. 1985: Stratigraphy and structure of the Fiskenæsset Complex, southern West Greenland. Bulletin Grønlands Geologiske Undersøgelse 150, $72 \mathrm{pp}$.

Polat A., Appel, P.W.U., Fryer, B., Windley, B., Frei, R., Samson, I.M. \& Huang, H. 2009: Trace element systematics of the Neoarchean Fiskenæsset anorthosite complex and associated meta-volcanic rocks, SW Greenland: evidence for a magmatic arc origin. Precambrian Research 175, 87-115.

Pornwilard, M.-M., Hansawek, R., Shiowatana, J. \& Siripinyanond, A. 2011: Geographical origin classification of gem corundum using elemental fingerprint analysis by laser ablation inductively coupled plasma mass spectrometry. International Journal of Mass Spectrometry 306, $57-62$.

Rakontondrazafy, A.F.M. et al. 2008: Gem corundum deposits of Madagascar: a review. Ore Geology Reviews 34, 134-154.

Schumacher, J.C., van Hinsberg, V.J. \& Keulen, N. 2011: Metamorphism in supracrustal and ultramafic rocks in southern West Greenland and South-West Greenland $64^{\circ}-61.5^{\circ} \mathrm{N}$. Danmark og Grønlands Geologiske Undersøgelse Rapport 2011/6, 29 pp.

Schwarz, D. et al. 2008: Rubies and sapphires from Winza, Central Tanzania. Gems \& Gemology 44, 322-347.

Thirangoon, K. 2008: Ruby and pink sapphire from Aappaluttoq, Greenland. Status of on-going research. Unpublished report for True North Gems Co. (In archives of Geological Survey of Denmark and Greenland, GEUS Report File 23642, 18 pp.). 